\title{
PEMEROLEHAN BAHASA ANAK USIA 3-4 TAHUN DI DESA TEGALREJO BANYUWANGI DALAM KAJIAN PSIKOLINGUISTIK
}

\author{
Ali Manshur ${ }^{1}$, Rikha Nahrul Jannah ${ }^{2}$ \\ e-mail: alimanshur@iaida.ac.id ${ }^{1}$, rihaenjhe03@gmail.com ${ }^{2}$ \\ Prodi Tadris Bahasa Indonesia \\ IAI Darussalam Blokagung Banyuwangi
}

\begin{abstract}
Abstrak
Tujuan penelitian ini adalah untuk mengetahui bentuk serta faktor dari pemerolehan bahasa anak usia 3-4 tahun. Penelitian ini mengkaji dalam ranah psikolinguistik, karena proses berbahasa pada anak tidak lepas dari psikologi dalam diri manusia. Penelitian ini menggunakan jenis kualitatif deskriptif. Pengambilan data menggunakan teknik observasi, wawancara, dan dokumentasi. Objek penelitian anak usia 3-4 tahun. Analisis data menggunakan model analisis data interaktif yang dikemukakan oleh Milles dan Hubermen meliputi pengumpulan data, reduksi data, penyajian data, dan penarikan kesimpulan. Hasil dari penelitian ini adalah anak berusia 3 tahun sudah mampu berkomunikasi dengan lawan tuturnya menggunakan kalimat-kalimat sederhana. Pelafalan huruf konsonan /r/ dan gugus konsonan belum dikuasai. Anak yang dalam usia 3,5 tahun dapat mengujarkan kalimat deklaratif, introgatif. Penguasaan terhadap beberapa benda disekitarnya dapat ia ungkapkan melalui bercerita. Anak berusia 4 tahun produksi bahasanya sudah meningkat. Faktor pemerolehan bahasa adalah biologis, lingkungan, kognitif, dan media elektronik yang sering diakses seperti gawai dan televisi.
\end{abstract}

Kata Kunci: Pemerolehan Bahasa, Faktor Pemerolehan Bahasa

\begin{abstract}
This research will discuss the form of language acquisition for children aged 3-4 years and what factors influence language acquisition in children aged 3-4 years. In this case the researcher studies in the realm of psycholinguistics, because the language process in children is inseparable from psychology in humans.

This research uses descriptive qualitative type. Retrieval of data using observation, interviews, and documentation techniques. The object of this study was children aged 3-4 years. Data Analisys from this reseach is The use of data analisys model interaktif according from Milles and Huberman is data collectif, data reducsi, data presentation, adn conclusion.

The results and conclusions of this study are that 3-year-old children are able to communicate with their interlocutors using simple sentences. Consonantal pronunciation $/ r /$ and consonant groups are not yet mastered. Children who are 3.5 years old can say declarative, introgative sentences. Mastery of several objects around him can he express through storytelling. Consonantal
\end{abstract}


pronunciation / $r /$ and consonant groups are not yet mastered. Children aged 4 years have increased language production. Language acquisition factors for children aged 3-4 years are biological, environmental, cognitive, and electronic media that are often accessed such as devices and television.

Key Word: Language Acquisition, Factors Influence Language Acquisition

\section{A. Pendahuluan}

Bahasa merupakan suatu sistem lambang bunyi yang arbitrer dan kemudian digunakan oleh beberapa orang dalam suatu kelompok sosial yang berguna untuk melakukan suatu kerjasama, berkomunikasi, serta mengidentifikasikan diri (Kridalaksana, 1983 dalam Yosep Trinowismanto). Terdapat pengertian bahasa yang diungkapkan oleh Sudaryono bahwa bahasa adalah suatu sarana komunikasi bagi seseorang yang paling efektif digunakan walaupun dalam penuturannya kurang sempurna sehingga menjadikan ketidaksempurnaan bahasa menjadi sebuah sarana komunikasi salah satu sumber terjadinya kesalah pahaman (Jauhar, 2011: 48). Bahasa memegang peranan yang penting dalam kehidupan manusia karena dengan bahasa manusia bisa berinteraksi atau berkomunikasi dengan manusia lainnya. Suatu proses bahasa ini terdiri atas bagian fisik baik itu berupa mulut, telinga, dan bagian dalam seperti jiwa dan akal yang kemudian terhubung melalui otak sebagai pusatnya. Berbicara merupakan keterampilan berbahasa yang membutuhkan rasa percaya diri peserta diri untuk mengungkapkan setiap gagasan melalui lisan (Hikmah, 2021:60).

Psikolinguistik adalah cabang ilmu linguistik yang membahas suatu hal yang berkaitan dengan proses pemerolehan bahasa pada anak, serta untuk menginterpretasikan produksi bahasa yang terjadi pada otak manusia. Kajian psikolinguistik nantinya akan memberikan kajian terkait pemerolehan bahasa. Pemerolehan bahasa pada manusia diawali dari seorang anak ketika belajar berbicara. Pemerolehan bahasa adalah suatu proses yang berlangsung di dalam otak seorang anak ketika dia memperoleh bahasa pertamanya atau bahasa ibunya (Abdul Chaer, 2015: 167). Seorang ibu dapat membantu menyalurkan stimulus pada anak. Sejalan dengan kemampuan pada anak serta kematangan jasmani anak maka proses berbahasa dan komunikasi nantinya akan semakin membaik, meningkat, serta meluas. Anak usia 3-4 tahun sudah mampu menghasilkan 
kalimat, baik itu dalam bentuk berita atau bahkan dapat menceritakan pengalaman singkat pribadinya masing-masing. Ujaran seorang anak berbeda pula dengan ujaran orang dewasa. Ujaran anak yang belum dapat sempurna ditandai dengan munculnya bentuk tuturan yang sederhana dan bunyi yang dapat berubah.

Proses pemerolehan bahasa anak ini juga dapat dipengaruhi oleh lingkungannya. Menurut Junadi (2021:72) menjelaskan bahasa juga bisa diartikan sebagai media untuk mengapresiasikan sesuatu yang terpendam di dalam diri seseorang. Seperti orang tua, teman, lingkungan, bahkan dari media yang sering diakses, misalnya youtube. Rofiq (2021:43) menyatakan bahwa bahasa adalah kebiasaan yang terlulang berkali-kali. Semakin sering anak melihat dan mendengar media tersebut, maka akan berpengaruh pula dengan perkembangan pemerolehan bahasanya. Hal ini dikarenakan dalam fase usia 3-4 tahun otak mereka berkembang sangat cepat sehingga informasi atau bahasa apapun akan cepat diserap olehnya. Dari sini lah peneliti dapat menemukan suatu problematika terkait pemerolehan bahasa pada anak usia 3-4 tahun. Tujuan dari penelitian ini adalah untuk mengetahui proses pemerolehan bahasa dan faktor-faktor yang memengaruhi pemerolehan bahasa pada anak usia 3-4 tahun.

\section{B. Metode Penelitian}

Penelitian kualitatif deskriptif adalah berupa penelitian dengan metode atau pendekatan studi kasus (case study). Penelitian ini memusatkan diri secara intensif pada satu obyek tertentu yang mempelajarinya sebagai suatu kasus (Moleong, 2011: 109). Dalam penelitian ini peneliti mengambil lokasi di Desa Tegalrejo Kecamatan Tegalsari Kabupaten Banyuwangi tepatnya di RT.02 RW.01. Informan penelitian ini adalah anak usia 3-4 tahun beserta orang tuanya. Sumber data diperoleh dari data primer, skunder. Prosedur pengumpulan data peneliti melakukan observasi, wawancara, dan dokumentasi.

Keakuratan, keabsahan, dan kebenaran data yang dikumpulkan dan dianalisis dari awal penelitian akan menentukan kebenaran serta ketepatan hasil penelitian sesuai dengan masalah dan fokus penelitian. Dalam uji kredibilitas ini, peneliti menggunakan sebuah cara dengan mengumpulkan bahan referensi yang tepat. Data yang sudah dikumpulkan dan ditulis dari lapangan baik itu berupa percakapan, wawancara, vidio dapat buat perbandingan untuk ketepatan dengan 
pendapat yang dikemukakan oleh para ahli dan dalam referensi yang telah terkumpul (Yusuf, 2017: 397).

Analisis data merupakan langkah berikutnya setelah semua data dan informasi terkumpul. Pola pikir yang akan digunakan dalam penelitian ini adalah pola pikir induktif. Sedangkan proses analisa data menggunakan prosedur analisa model Milles dan Huberman, yaitu pengumpulan data, reduksi data, penyajian data, dan penarikan kesimpulan.

\section{Hasil Dan Pembahasan}

Setelah mengetahui paparan data diatas, maka peneliti menemukan suatu hasil dan pembahasan penelitian sebagai berikut:

\section{Pemerolehan Bahasa Anak Usia 3-4 Tahun}

Pemerolehan bahasa terjadi sejak usia dini. Dalam perkembangan bahasa terdapat Language Acquistion Device (LAD) yang merupakan alat untuk pemerolehan bahasa yang merupakan pemberian biologis yang dibawa sejak lahir oleh anak. Anak berusia 3-4 tahun, ia berada dalam fase deferensiasi. Di periode ini bahasa anak sudah dikatakan baik, meskipun terkadang masih kesulitan dalam mengucapkan huruf konsonan.

Dari hasil wawancara peneliti data bahwa informan dari penelitian ini adalah seorang anak bernama Muhammad Arif Rifqi yang berusia kurang lebih 3 tahun. Di usianya 3 tahun ia sudah mampu berkomunikasi. Meskipun terkadang respon dari anak tersebut keluar dari topik pembicaraan. Hal ini menunjukkan bahwa perkembangan kognitifnya sangat baik. Pengalaman yang ia lakukan sudah dapat ia ungkapkan melalui bercerita dengan lawan komunikasinya. Informan kedua adalah Muhammad Akma Abrizam. Diusia 3,5 tahun anak tersebut sudah mampu mengucapkan kalimat introgatif dan dapat menyebutkan beberapa macam warna. Informan mengetahui pengetahuan diatas melalui tontonan sehari-harinya. Kemampuan dalam melafalkan huruf konsonan /r/ juga mulai meningkat, walaupun harus diberikan stimulus terlebih dahulu oleh ibunya. Ainayya Sayyida Nasifa merupakan informan ketiga yang berusia 4 tahun. dapatkan sebuah hasil bahwa belum ada kesempurnaan dalam mengucapkan salam. Hilangnya beberapa huruf vokal dan huruf konsonan. Kata “Assalamualaikum” menjadi “ 
Assalamekum”, "Wabarokatu" menjadi “Abalokatu”, dan masih kesulitan dalam melafalkan huruf /r/. Informan selanjutnya yaitu Muhammad Al Azam, berusia 3,5 tahun. Data diambil dari proses komunikasi antara peneliti dan informan yang dilakukan di dapur, maka diperoleh hasil anak tersebut dapat menyebutkan bendabenda yang berada disekelilingnya. Menyebutkan jenis sayur, lauk-pauk, dan beberapa rasa makanan. Apa yang ada dalam fikiran anak tersebut ia ungkapkan dengan melibatkan anggota tubuhnya. Hal ini menunjukkan bahwa anggota tubuh dan otak juga menjadi faktor pendukung dari perkembangan bahasa anak. Perkembangan kognitif juga ada keterkaitan dengan gerak motorik anak. Informan yang ke lima adalah Ikmala Kanza Az-Zahra. Penelitian dilakukan dengan menganalisis video yang innforman buat. Dari video tersebut menghasilkan suatu data bahwa anak berusia 4 tahun, ia sudah memiliki banyak pembendaharaan kata. Ia sudah mampu merangkai beberapa kalimat, terdapat beberapa kata yang belum sempurna. Hilangnya huruf konsonan /r/ dari kata "Sumatera" menjadi "Sumata". Faktor yang memengaruhi pemerolehan bahasa serta perkembangan bahasanya adalah lingkungan dan media elektronik yang sering diakses.

2. Faktor Yang Memengaruhi Pemerolehan Bahasa Pada Anak Usia 3-4 Tahun

Seperti yang telah dipaparkan pada pembahasan teori-teori pemerolehan bahasa, bahwasannya terdapat tiga aliran dalam pemerolehan bahasa anak, yaitu aliran nativisme, behaviorisme, dan yang terakhir adalah aliran kognitivisme. Ketiga aliran tersebut secara bersama dapat digunakan untuk menjelaskan proses pemerolehan bahasa, karena teori ini dapat dibuktikan kebenarannya. Anak yang baru dilahirkan telah memiliki potensi jiwa yang dapat dipakai untuk menganalisis apa yang didengar dari lingkungannya. Seorang anak dapat mengembangkan kemampuan apabila anak tersebut berada dalam lingkungan pemakaian bahasa. Disamping itu sejak dilahirkan seorang anak sudah memiliki potensi berbahasa, dan lingkunganpun juga berperan aktif membentuk bahasa seorang anak.

Hal ini dapat dibuktikan dengan penelitian melalui wawancara yang dilakukan peneliti dengan orang tua informan yang telah dilakukan di Desa Tegalrejo RT.02 RW.01 Tegalsari Banyuwangi. Hasil dari penelitian ini adalah anak yang dalam fase usia 3-4 tahun sudah mengalami perkembangan bahasa yang baik. Produksi kata dan kalimat juga berkembang pesat. Di bidang fonologi 
sudah dikatakan baik, meskipun terkadang masih kesulitan dalam mengucapkan huruf konsonan dan gugus konsonan. Penguasaan tentang ruang dan waktu juga sudah terlihat. Fungsi bahasa sebagai alat komunikasi sudah dapat dilakukan sekalipun itu dengan orang dewasa.

Dari beberapa perkembangan bahasa yang telah dipaparkan merupakan bentuk dari pemerolehan bahasa anak usia 3-4 tahun. Tentu dalam hal ini tidak terlepas dari faktor yang dapat memengaruhi terhadap pemerolehan bahasa anak. Sesuai dengan teori pemerolehan bahasa yaitu nativisme (natural), maksudnya adalah bawaan biologis karena memang sejak dalam kandungan seorang bayi sudah dianugerahi kemampuan berbahasa, oleh sebab itu ketika ia dilahirkan maka akan memeroleh bahasa secara alamiah. Seiring dengan bertambahnya usia anak, maka produksi bahasanyapun kian bertambah. Seperti yang telah dipaparkan oleh orang tua informan, bahwa pada awal anaknya dapat memproduksi kata pada usia kurang lebih 1 tahun. Kata yang sering diucapkan adalah "tu, bu, bah, aem, mbah, nyo-nyo". Setelah itu anak mulai dapat berkomunikasi dengan orang-orang sekelilingnya itu pada usia 1 tahun lebih, akan tetapi dalam pengucapannya belum begitu jelas. Baru ketika anak tersebut memasuki usia 3 tahun, ia dapat merespon mitra tuturnya secara baik.

Dari penjelasan diatas, tentu ada faktor lain untuk dapat menunjang pemerolehan bahasanya, yaitu dengan adanya komunikasi yang baik antara anak dan lingkungan sekitarnya, terutama dalam lingkup keluarga. Semakin sering anak memeroleh stimulus, maka responnya pun juga akan semakin meningkat baik. Informan (orang tua) juga mengungkapkan bahwa anggota keluarga seperti ayah, kakak, nenek, kakek dan mitra tutur lainnya tentu memberikan pengaruh dalam perkembangan bahasa anak. Ketika anak tersebut sudah terbiasa dalam berkomunikasi, maka produksi bahasa, kemampuan berbahasa, serta penyusunan kalimatnya pun juga akan terus meningkat pesat. Bahkan peneliti menemukan data bahwa anak diusia 3-4 tahun ia memiliki antusias tinggi dalam merespon lawan tuturnya. Bahkan terkadang anak tersebut yang mengawali pembicaraan dengan topik yang ia inginkan. Wujud dari komunikasi ini adalah ia bercerita tentang pengalaman pribadinya bahkan menceritakan segala sesuatu yang ia ketahui. Dari faktor yang telah dikemukakan orang tua informan, maka teori 
behaviorisme dapat dibenarkan. Teori ini menjelaskan bahwa pemerolehan bahasa anak dipengaruhi pula oleh lingkungan sekitarnya.

Selain dari faktor pembawaan pada anak (biologis) dan lingkungan, ditemukan pula data bahwa media lain juga dapat menunjang pemerolehan bahasa dan perkembangan bahasa. Media yang dimaksudkan disini adalah media elektronik, yaitu televisi dan gawai. Dua media ini merupakan benda yang sering anak gunakan dalam kehidupan sehari-hari. Biasanya mereka menonton kartun melalui dua alat elektronik ini. Anak diusia 3-4 tahun juga sudah mampu mengakses media sosial seperti youtube. Sesuai dengan fungsi media, yaitu sebagai alat menyampaikan suatu informasi dan komunikasi, maka media tersebut akan memberikan pengaruh pula pada perkembangan dan pemerolehan bahasa anak. Semakin sering anak melihat dan mendengar media tersebut, maka akan berpengaruh pula dengan perkembangan pemerolehan bahasanya. Suatu tontonan yang disediakan secara inten, teratur dan berlangsung dalam waktu yang lama tentunya akan dapat memengaruhi pemerolehan bahasa anak, sehingga seorang anak akan dengan mudah menirukan ujaran tersebut, baik dari televisi, gawai, youtube atau yang lainnya tanpa anak mengetahui apa maksud dan makna yang terkandung didalamnya. Hal ini dikarenakan dalam fase usia 3-4 tahun otak mereka berkembang sangat cepat sehingga informasi atau bahasa apapun akan cepat di serap olehnya. Melalui media ini anak dapat menemukan beberapa kosa kata baru bahkan kata yang ia peroleh berasal dari bahasa inggris seperti, "byebye, guys, subcribe, no". Hal ini tentu dapat menambah pembendaharaan kata pada anak. Dapat kita simpulkan bahwa media yang sering diakses dapat menunjang serta menjadi faktor terhadap pemerolehan bahasa anak. Kecepatan dan ketanggapan mereka dalam menyerap beberapa kosa kata baru yang ia peroleh dari media yang sering diakses, maka ini menandakan bahwa perkembangan kognitifnya sangat baik. Kematangan kognitif pada seseorang juga memengaruhi terhadap kemampuannya dalam menyerap informasi yang ia dapat. Bahkan kemampuan kognitif yang baik juga akan sangat membantu seorang anak dalam berkomunikasi. Mereka akan cepat memahami berbagai hal yang ada di sekitarnya. Hal ini juga sangat membantu perkembangan kecerdasan seorang anak baik intelektual juga emosionalnya karena ia sudah terlatih untuk memahami dan 
merespon. Beberapa kemampuan yang dimiliki anak yang bersumber dari kematangan kognitif. Perkembangan bahasa harus berpondasikan pada suatu perubahan yang mendasar dan lebih umumnya di dalam kognisi, oleh karena itu perkembangan kognitif anak tentu sangat menentukan perkembangan bahasa pada anak.

Dari wawancara yang dilakukan peneliti dengan informan (orang tua) diperoleh suatu data bahwa seorang anak yang tidak terbiasa berinteraksi dengan orang sekitar baik orang tua, teman, dan orang lain pada kesehariannya maka akan mempengaruhi kemampuannya dalam memahami bahasa serta produksi bahasa dengan baik. Tidak hanya itu, seorang anak tersebut juga akan kehilangan rasa percaya dirinya sehingga proses komunikasi pun sulit untuk dilakukan.

Dari penelitian, paparan data, temuan, dan pembahasan peneliti dapat menyimpulkan bahwa terdapat beberapa faktor yang memengaruhi pemerolehan bahasa anak usia 3-4 tahun, yaitu faktor biologis atau bersifat alamiah (nativisme), lingkungan (behaviorisme), kognitif (kognitivisme), serta media yang sering diakses. Hasil penelitian ini dapat membenarkan dari teori-teori pemerolehan bahasa serta menjawab dari rumusan masalah penelitian.

\section{Kesimpulan}

Anak yang berusia 3 tahun sudah mampu berkomunikasi dengan lawan tuturnya dengan baik. Pengetahuan serta pengalaman pribadinya ia ungkapkan melalui bercerita menggunakan kalimat-kalimat sederhana. Proses interaksi dengan anak usia 3,5 tahun dapat berjalan baik. Informan dapat melontarkan beberapa bentuk kalimat, seperti deklaratif (berita), introgatif (tanya). Penguasaan terhadap beberapa benda telah mampu ia kuasai, seperti macam-macam warna, buah, sayur, dan alat transportasi. Anak yang sudah berusia 4 tahun dalam hal memproduksi kata dan kalimat sudah meningkat, hanya saja dalam penyusunan kalimat belum baku. Huruf konsonan /r/ sudah mampu ia lafalkan, tetapi gugus konsonan belum. faktor yang memengaruhi pemerolehan bahasa anak usia 3-4 tahun, yaitu faktor biologis atau bersifat alamiah, lingkungan, kognitif, serta media yang sering diakses. 
Berdasarkan dari hasil temuan dalam penelitian, terdapat beberapa hal yang harus diperhatikan, yaitu:

1. Bagi peneliti selanjutnya, penelitian ini hanya membahas seputar pemerolehan bahasa anak usia 3-4 tahun. Masih terdapat beberapa aspek ilmu yang belum dibahas dalam penelitian kali ini.

2. Bagi masyarakat sebaiknya untuk lebih memerhatikan terkait perkembangan bahasa serta pemerolehan bahasa pada anak.

\section{Daftar Pustaka}

Ahmadi, Anas \& Jauhar, Muhammad. 2015. Dasar-Dasar Psikolinguistik. Jakarta: Prestasi Pustakaraya.

Chaer, Abdul. 2015. Psikolinguitik: Kajian Teoritis. Jakarta: PT RINEKA CIPTA.

Muleong. 2011. Metode Penelitian Kualitatif. Bandung: PT REMAJA ROSDAKARYA.

Asngadi Rofiq, K. A. N. (2021). Proses Morfologis Reduplikasi dalam Buku Generasi Optimis Karya Ahmad Rifa'i Rif'an. PENEROKA, 1(01), 42-59.

Hikmah, S. N. A. H. (2021). Problematika Pencapaian Kompetensi Keterampilan Berbicara Siswa dalam Pembelajaran Bahasa Indonesia. PENEROKA, 1(01), 59-67.

Syafi' Junadi, R. K. L. (2021). Fenomena Bahasa Gaul sebagai Kreativitas Linguistik dalam Media Sosial Instagram pada Era Milenial. PENEROKA, $1(01), 68-89$.

Trinowismanto, Yosep. 2016. Pemerolehan Bahasa Pertama Anak Usia 0 s.d 3 Tahun Dalam Bahasa Sehari-Hari (tinjauan Psikolinguistik). Jurnal Bahasa Indonesia (Online). Diakses Pada Tanggal 8 Mei 2020.

Yusuf, Muri. 2017. Metode Penelitian Kuantitatif, Kualitatif, Dan Penelitian Gabungan. Jakarta: Kencana. 